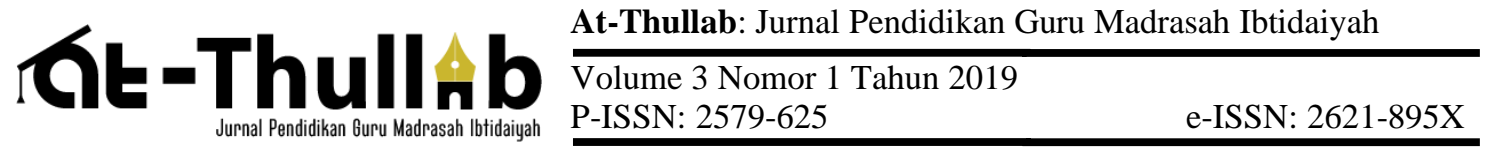

\section{MENINGKATKAN KEMAMPUAN MINDS-ON DAN HANDS-ON SISWA MATERI BANGUN DATAR DENGAN MENGGUNAKAN METODE TALKING STICK}

\author{
${ }^{1}$ Musaadatul Fithriyah, ${ }^{2}$ Shinta Silviatun Najah, ${ }^{3}$ Fatimah \\ $1,2,3$ Universitas Islam Lamongan

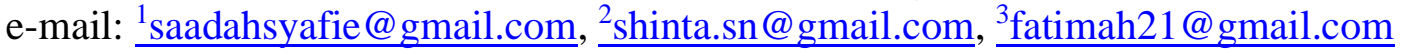

\begin{abstract}
Learning materials in two-dimentional figure in class II at MI Sunan Giri Merjosari Malang there are several problems namely students tend to be passive and the learning atmosphere is less pleasant because the teacher is more dominant using the lecture method so that the impact on student learning outcomes is less than the specified KKM 75 amounting to $60 \%$ of the 20 overall total students. One of the ways to improve the quality of student learning is to apply learning methods that later learning objectives can also be maximally achieved. Very diverse learning methods adapted to the material and objectives to be achieved include talking stick method including one of the learning methods carried out with the help of a stick and in turn will be held by students and who hold the mandatory answer questions from the teacher. Learning with the talking stick method is very suitable to be applied in elementary, because it can train students cognitive and psychomotor abilities, besides that the learning atmosphere is also fun and active students. This talking stick method is very appropriate to be used in the development of students' minds-on and hands-on. The purpose of this study was to determine the application of the talking stick method and the improvement of the mindson and hands-on abilities of students in the Flat Build Class II MI Sunan Giri Merjosari Lamongan after using the talking stick method. Researchers conducted using a qualitative approach to the type of classroom action research (CAR). Analysis of the data used is descriptive qualitative techniques. The sequence of research activities includes 4 stages including: (1) Planning, (2) Implementation, (3) Observation, and (4) Reflection. The results of the study obtained the results of the assessment of learning outcomes of the two-dimentional figure material both cycle I and cycle II of Minds-on ability in cycle I amounted to 82.25 compared to the value of Minds-on in cycle II amounted to 85.5 an increase of 3.25. Likewise with the Hans-On ability assessment there was also an increase between Cycle I an average value of 75.45 and a second cycle of 80.95 an increase of 5.5. Based on the results of the analysis of the research data it can be concluded that the use of the talking stick method can improve the mindson and hands-on abilities of thematic learning in Class II theme 4 Flat Build Material and its properties in MI Sunan Giri Merjosari Malang and its implementation can run effectively and efficient.
\end{abstract}

Keywords: Mids-on and Hands-On, Talking Stick. 


\section{A. Pendahuluan}

Dewasa ini telah banyak kasus yang mengakibatkan penurunan hasil belajar siswa, terutama materi matematika karena banyak faktor yang mempengaruhinya. Secara global faktor-faktor yang mempengaruhi hasil belajar siswa dapat dibedakan menjadi tiga macam (Syah, 2010): (a) Faktor internal, yaitu faktor dalam siswa yang meliputi keadaan/kondisi jasmani dan rohani siswa. (b) Faktor eksternal, yaitu faktor luar siswa meliputi kondisi lingkungan di sekitar siswa. (c) Faktor pendekatan belajar (approach to learning), yaitu jenis upaya belajar siswa yang meliputi strategi dan metode yang digunakan siswa untuk melakukan kegiatan pembelajaran materi-materi pelajaran.

Berdasarkan faktor-faktor yang mempengaruhinya tersebut menuntut guru untuk lebih kreatif dalam proses pembelajaran, pada dasarnya berhasil atau tidaknya tercapainya tujuan pembelajaran tergantung pada pendidiknya, seorang pendidik adalah figur yang seharusnya membimbing siswa dan mendidik siswa untuk memperoleh pengetahuan, sikap dan keterampilan yang baik.

Mengembangkan metode pengajaran merupakan salah satu upaya untuk meningkatkan kualitas belajar siswa. Metode dalam proses belajar mengajar merupakan sebagai alat untuk mencapai tujuan, perumusan tujuan dengan sejelas-jelasnya merupakan syarat terpenting sebelum seseorang menentukan dan memilih metode mengajar yang tepat. Pemilihan metode mengajar yang kurang tepat akan menyebabkan kekaburan tujuan yang ingin dicapai (Afandi, 2013).

Seorang pendidik dituntut untuk menguasai metode karena dapat membantu untuk mempermudah tugasnya dalam menyampaikan mata pelajaran tersebut. Dan yang terpenting metode digunakan agar siswa mampu berperan aktif dalam pembelajaran.

Materi Bangun Datar merupakan salah satu materi Matematika di SD/MI yang bersifat kongkrit. Oleh karena itu perlu metode pembelajaran yang tepat agar materi Bangun Datar dapat bermakna bagi siswa.

Pada kenyataannya kegiatan belajar menggajar pembelajaran materi Bangun Datar di MI Sunan Giri Merjosari Malang terdapat permasalahan yaitu siswa lebih cenderung pasif dan suasana belajar kurang menyenangkan dikarenakan guru lebih dominan menggunakan metode ceramah sehingga berdampak pada hasil belajar siswa kurang dari KKM yang ditentukan 75 berjumlah 60\% dari 20 keseluruhan jumlah siswa.

Salah satu untuk meningkatkan kualitas belajar siswa yaitu menerapkan metode pembelajaran yang nantinya tujuan pembelajaran juga dapat tercapai secara maksimal. Metode pembelajaran sangat beraneka ragam disesuaikan dengan materi dan tujuan yang hendak dicapai diantaranya metode Talking Stick termasuk salah satu metode pembelajaran yang dilakukan dengan bantuan tongkat dan secara bergilir akan dipegang 
siswa dan yang memegang wajib menjawab pertanyaan dari guru. Pembelajaran dengan metode talking stick sangat cocok diterapkan di SD/MI, karena mapu melatih kemapuan kognitif dan psikomotor siswa, selain itu suasana belajar juga menyenangkan dan siswa aktif.

Metode Talking Stick ini sangat tepat digunakan dalam pengembangan minds-on dan hands-on. Dengan menggunakan metode Talking Stick, perkembangan psikomotor siswa dapat meningkat, karena menurut Ramadhan, Talking Stick (tongkat berbicara) adalah metode yang pada mulanya digunakan pleh penduduk asli Amerika untuk mengajak semua orang berbicara atau menyampaikan pendapat dalam suatu forum. tongkat berbicara sering digunakan di kalangan dewan untuk memutuskan siapa yang mempunyai hak berbicara (Gugus, Kecamatan, Heriasa, Arini, \& Rati, 2014).

Berdasarkan permasalahan di atas, perlu dilakukan penelitian dalam rangka meningkatkan kualitas pembelajaran materi Bangun Datar dengan judul "Meningkatkan Kemampuan Minds-On dan Hands-On Siswa pada Materi Bangun Datar dengan Menggunakan Metode Talking Stick Kelas II di MI Sunan Giri Merjosari Malang" dengan tujuan agar hasil belajar siswa dapat lebih baik.

\section{Metode Pembelajaran}

Metode berasal dari bahasa Greek yang terdiri dari " Meta " yang berarti jalan yang dilalui (Kusumo, 2017). metode dalam pengertian istilah telah dikemukakan oleh pakar dalam dunia pendidikan seperti Prof. Dr. Hasan Langgunung, mengatakan bahwa "Metode adalah suatu cara atau jalan yang dilalui untuk mencapai tujuan pendidikan" (Langgulung, 1988). Selain itu Direktoran Pembina PTAI "Metode adalah suatu cara siasat penyampaian bahan pengajaran tertentu dari suatu mata pelajaran agar siswa dapat mengetahui, memahami, mempergunakan dan dengan kata lain menguasai bahan pelajaran tersebut" (Direktorat Pembina PTAI 1985).

Berdasarkan pendapat di atas dapat ditarik kesimpulan bahwa metode merupakan suatu cara atau alat untuk mencapai tujuan, selain itu metode adalah suatu bagian dari komponen proses pendidikan.

Metode dianggap sebagai suatu cara yang digunakan untuk mancapai tujuan yang telah ditetapkan. Dalam kegiatan belajar mengajar, metode pembelajaran sangat diperlukan oleh guru, dengan penggunaan yang bervariasi dan sesuai dengan tujuan yang ingin dicapai. Menguasai metode pembelajaran merupakan keniscayaan, sebab seorang guru tidak akan mengajar dengan baik apabila tidak menguasai metode secara tepat. Metode dianggap sebagai cara atau prosedur yang keberhasilannya di dalam belajar atau sebagai alat yang menjadikan mengajar menjadi efektif (Sutikno \& Fathurrohman, 2010).

Menurut Syaiful Bahri Djamarah dan Winarno Surakhmad, mengemukakan bahwa lima macam faktor yang mempengaruhi penggunaan metode pembelajaran yaitu 
: (1) Tujuan dengan berbagai jenis dan fungsinya. (2) Anak didik dengan berbagai tingkat kematangannya. (3) Situasi berlainan keadaannya. (4) Fasilitas secara bervariasi secara kualitas dan kuantitasnya. (5) Kepribadian dan kompetensi guru yang berbedabeda.

Adapun macam-macam metode pembelajaran di antaranya sebagai berikut (Sanjaya, 2010): (1) Metode Ceramah; (2) Metode Diskusi; (3) Metode Demonstrasi; (4) Metode Karya Wisata; (5) Metode jigsaw; (6) Metode Think Pair Share; (7) Metode Talking stick; (8) Metode Tim Game Tournament

\section{Metode Talking Stick}

Menurut Ramadhan, talking stick (tongkat berbicara) adalah metode yang pada mulanya digunakan oleh penduduk asli Amerika untuk mengajak semua orang berbicara atau menyampaikan pendapat dalam suatu forum. Tongkat berbicara sering digunakan di kalangan dewan untuk memutuskan siapa yang mempunyai hak berbicara. Tongkat akan berpindah ke orang lain apabila ia ingin berbicara atau menanggapinya. Dengan cara ini tongkat berbicara akan berpindah dari satru orang ke orang lain jika orang tersebut ingin mengemukakan pendapatnya. Apabila semua mendapatkan giliran berbicara, tongkat itu lalu dikembalikan lagi ke ketua/pimpinan rapat (Indriani, 2013).

Penjelasan di atas, dapat disimpulkan bahwa Metode talking stick termasuk salah satu metode pembelajaran yang dilakukan dengan bantuan tongkat, siapa yang memegang tongkat wajib menjawab pertanyaan dari guru setelah siswa mempelajari materi pokoknya. Pembelajaran talking stick sangat cocok diterapkan di SD, karena selain melatih kemapuan psikomotor dan kognitif, pembelajaran ini menciptakan suasana yang menyenangkan dan membuat siswa aktif.

Suprijono mengatakan bahwa, "Metode talking stick mendorong peserta didik untuk berani mengemukakan pendapat". Metode talking stick ini sangat tepat digunakan dalam pengembangan minds-on dan hands-on anak (Agus Suprijono, 2010).

\section{1) Langkah-Langkah Metode Talking Stick}

Adapun langkah-langkah metode talking stick sebagai berikut (Sibuea \& Syahfitri, 2018):

a) Guru menyiapkan sebuah tongkat.

b) Guru menyampaikan materi pokok yang akan dipelajari secara singkat, kemudian memberikan kesempatan kepada peserta didik untuk membaca dan mempelajari materi pegangannya.

c) Setelah selesai membaca buku dan mempelajarinya, peserta didik dipersilahkan untuk menutup bukunya.

d) Guru mengambil tongkat dan memberikan kepada siswa, setelah itu guru memberikan pertanyaan dan siswa yang memegang tongkat tersebut harus 
menjawabnya dan seterusnya, sampai sebagian besar siswa mendapat bagian untuk menjawab setiap pertanyaan guru.

e) Siswa yang berhasil menyelesaikan soalnya dengan menjawab dengan baik akan mendapatkan smile tag dari guru.

f) Guru memberikan kesimpulan dan tambahan jawaban yang kurang benar dari siswa.

g) Evaluasi

h) Penutup.

2) Kelebihan dan Kekurangan Metode Talking Stick

a) Kelebihan metode Talking Stick yaitu; dapat menguji kesiapan siswa, melatih siswa membaca dan memahami materi dengan cepat, Memacu siswa agar lebih giat belajar, Siswa berani mengemukakan pendapat, Meningkatkan kemampuan psikomotor dan kognitif pada diri siswa.

b) Kekurangan metode Talking Stick yaitu; membutuhkan waktu yang cukup lama, dan diperlukan persiapan yang cukup matang oleh guru sebelum menerapkan dalam pembelajaran.

\section{Bangun Datar}

Bangun datar dapat didefinisikan sebagai bangun yang rata yang mempunyai dua dimensi yaitu panjang dan lebar tetapi tidak mempunyai tinggi dan tebal. Benda-benda dilihat dengan mata telanjang terlihat rata atau datar belum tentu memenuhi syarat untuk digolongkan sebagai bangun datar. Dengan demikian pengertian bangun datar adalah abstrak (Tarigan, 2018).

\section{Bentuk-Bentuk Bangun Datar}

Bentuk-bentuk bangun datar antara lain (Heruman, 2008), yaitu:

a) Persegi merupakan bangun datar yang memiliki empat sisi sama panjang dan bentuk keempat sudutnya siku-siku.

b) Persegi panjang merupakan bangun datar yang memiliki empat sisi, bentuk keempat sudutnya siku-siku dan sepasang-sepasang sisi yang berhadapan sama panjang.

c) Segitiga merupakan bangun datar yang terbentuk dari penghubungan tiga buah titik yang tidak segaris.

d) Trapesium merupakan bangun segiempat yang memiliki empat sisi, panjang sisinya tidak sama, tidak semua bentuk sudutnya siku-siku dan memiliki dua sisi yang sejajar. Pada umumnya, trapesium terbagi atas tiga jenis, yaitu trapesium sembarang, trapesium sama kaki, dan trapesium siku-siku

e) Jajar genjang merupakan bangun datar yang memiliki empat sisi, sisi yang sejajar sama panjang, semua sudutnya tidak siku-siku, dan memiliki sepasang sisi sejajar

f) Layang-layang adalah segiempat yang sepasang sisinya berdekatan sama panjang dan sepasang sudut yang berhadapan sama besar. 
g) Lingkaran merupakan bangun datar yang terbentuk dari himpunan semua titik persekitaran yang mengelilingi suatu titik asal dengan jarak yang sama, jarak tersebut biasanya dinamakan $r$ atau radius, atau jari-jari (Suharjana, 2008).

Penelitian ini dilakukan pada pembelajaran Tematik kelas II SD/MI tema 4 materi Bangun Datar Sederhana Dan Mengenal Ciri-Ciri Bangun Datar.

\section{Kemampuan Minds-on dan Hands-on}

\section{1) Kemampuan Minds-on}

Chaplin mengatakan bahwa kemampuan mins-on (disebut juga kemampuan kognitif), kemampuan psikologis manusia yang yang meliputi setiap perilaku mental yang berhubungan dengan pemahaman, pertimbangan, pengolahan informasi, pemecahan masalah, kesengajaan, dan keyakinan (Syah, 2010).

\section{2) Kemampuan Hands-on}

Kemampuan hands-on (disebut juga psikomotor) merupakan kemampuan yang progresif dan berhubungan dengan perolehan aneka ragam ketrampilan fisik anak (motor skill). Menurut Howe, hal ini mengingat pola-pola gerakan yang cakap dan terkoordinasi itu tak dapat mencapai dengan baik semata-mata dengan mekanisme sederhana, tetapi dengan menggunakan proses mental yang sangat kompleks (Desmita, 2010).

\section{B. Metode}

\section{Rancangan Penelitian}

Penelitian ini dirancang dengan menggunakan pendekatan penelitian kualitatif dengan jenis Penelitian Tindakan Kelas (PTK/classroom action research) yakni suatu penelitian yang mengkaji proses pembelajaran dikaitkan dengan pengoptimalan penggunaan metode, media, strategi pembelajaran, di mana kegiatan perbaikan pembelajaran tersebut diharapkan dapat meningkatkan proses dan hasil pembelajaran siswa (Hendriana \& Afrilianto, 2017). PTK bertujuan untuk memberikan sumbangan nyata bagi peningkatan profesionalisme, menyiapkan pengetahuan, pemahaman, dan wawasan tentang perilaku guru mengajar dan murid (Arikunto, 2006).

Dalam penelitian tindakan kelas ini, peneliti melaksanakan melalui dua siklus yaitu siklus I dengan 2 kali pertemuan dan siklus II juga 2 kali pertemuan. Rancangan PTK yang digunakan pada penelitian ini menggunakan model spiral penelitian tindakan kelas dari Arikunto yang meliputi 4 tahap perencanaan, pelaksanaan tindakan, observasi, dan refleksi.

\section{Kehadiran Peneliti}

Pada penelitian yang menggunakan pendekatan kualitatif yang menjadi alat utama adalah manusia, artinya melibatkan penelitinya sendiri sebagai instrumen, dengan 
memperhatikan kemampuan penelitinya sendiri sebagai instrumen dalam hal bertanya, melacak, mengamati, memahami, dan mengabstrasikan sebagai alat penting yang tidak dapat diganti dengan cara lain (Wahidmurni, 2008).

Kehadiran peneliti di lapangan sangat diperlukan sebagai instrumen sekaligus pengumpul data. Selain itu peneliti juga mempunyai kedudukan sebagai perencana, pelaksana, pengumpul data dan penganalisis, serta pelapor data. Selama kegiatan penelitian berlangsung, peneliti dibantu oleh guru kelas II sebagai pengamat. Hal ini dimaksudkan pengamat lain dapat memberikan informasi data lebih lengkap apabila peneliti kurang cermat dalam mengumpulkan data.

\section{Subyek Penelitian}

Dalam Penelitian Tindakan Kelas ini yang menjadi subjek penelitian adalah siswa kelas II MI Sunan Giri Merjosari Malang Tahun Ajaran 2018-2019 yang terdiri dari 20 siswa.

\section{Waktu dan Lokasi Penelitian}

Penelitian ini dilakukan mulai bulan November 2018 dan dilaksanakan di MI Sunan Giri Merjosari Malang karena kemampuan Hands-on dan Mind-on siswa rendah pada pembelajaran materi Bangun Datar.

\section{Data dan Sumber Data}

Pada penelitian kali ini yang dijadikan subyek penelitian adalah siswa kelas II di MI Sunan Giri Merjosari Malang, di mana siswa menjadi subyek penelitian dan juga aktif dalam kegiatan yang dilakukan. Berikut data dan sumber data yang peneliti gunakan :

Tabel 1. Sumber dan Jenis Data

\begin{tabular}{|l|l|l|}
\hline No. & \multicolumn{1}{|c|}{ Jenis Data } & \multicolumn{1}{|c|}{ Sumber Data } \\
\hline 1. & Hasil tes awal dan tes akhir. & Siswa \\
\hline 2. & $\begin{array}{l}\text { Wawancara permasalahan hasil belajar, langkah- } \\
\text { langkah pembelajaran yang biasa digunakan di } \\
\text { kelas. }\end{array}$ & $\begin{array}{l}\text { Kepala Madrasaha, } \\
\text { Waka kurikulum, dan } \\
\text { Guru }\end{array}$ \\
\hline 3. & $\begin{array}{l}\text { Aktivitas antara guru dan siswa selama proses } \\
\text { pembelajaran. }\end{array}$ & Guru dan Siswa \\
\hline
\end{tabular}

\section{Teknik Pengumpulan Data}

Data yang akurat akan bisa diperoleh ketika proses pengumpulan data tersebut dipersiapkan dengan matang. Dalam penelitian ini akan digunakan beberapa cara untuk mengumpulkan data selama proses penelitian (Sutikno \& Fathurrohman, 2010). Teknik pengumpulan data yang digunakan peneliti dalam penelitian tindakan kelas meliputi; 

a. Observasi
b. Wawancara
c. Tes individu dan kelompok
d. Dokumentasi

\section{Analisis Data}

Analisis data kualitatif yang dikutip oleh Moleong adalah upaya yang akan dilakukan dengan jalan bekerja dengan data, mengorganisasikan data, memilahmilahnya menjadi satuan yang dapat dikelola, mensintesiskannya, mencari dan menemukan pola, menemukan apa yang penting dan apa yang dipelajari, dan memutuskan apa yang dapat diceritakan kepada orang lain (Moleong, 2017).

Data yang diperoleh dari tindakan dianalisis dengan teknik analisis deskriptif kualitatif untuk memastikan bahwa dengan mengaplikasikan metode talking stick dapat meningkatkan kemampuan minds-on dan hands-on siswa. Data yang bersifat kualitatif, terdiri dari hasil observasi, wawancara, dan dokumentasi dianalisis secara kualitatif. Sedangkan data yang dikumpulkan berupa angka atau data kuantitatif cukup dengan menggunakan analisis deskriptif dan sajian visual. Sajian tersebut untuk menggambarkan bahwa dengan tindakan yang akan dilakukan dapat menimbulkan adanya perbaikan, peningkatan, atau perubahan ke arah yang lebih baik, jika dibandingkan dengan keadaan sebelumnya.

Proses analisis data yang dilakukan oleh peneliti yaitu dengan langkah-langkah sebagai beikut: (a) Reduksi Data, (b) Display data atau penyajian data, (c) Menarik kesimpulan atau verifikasi

\section{Pengecekan keabsahan hasil penelitian}

Pengecekkan keabsahan hasil penelitian dimaksudkan dengan usaha-usaha yang dilakukan pneliti untuk memeperoleh keabsahan temuan. Pengambilan data melalui tiga tahap, yaitu tahap pendahuluan, tahap penyaringan, dan tahap melengkapi data yang masih kurang. Ketiga tahap itu untuk pengecekan keabsahan data banyak terjadi pada tahap penyaringan data. Oleh sebab itu, jika terdapat data yang tidak relevan dan kurang memadai maka akan dilakukannya penyaringan data sekali lagi dilapangan sehingga data itu memiliki kadar validitas yang tinggi.

Moleong berpendapat bahwa, "dalam penelitian diperlukan suatu teknik pemeriksaan keabsahan data. Sedangkan untuk memperoleh keabsahan temuan perlu diteliti kredibilitasnya dengan menggunakan teknik sebagai berikut:

a. Persistent observation (ketentuan pengamatan) yaitu mengadakan observasi secara terus menerus terhadap obyek penelitian guna memahami gejala lebih mendalam terhadap berbagai aktivitas yang sedang berlangsung dilokasi penelitian.

b. Triangulasi yaitu pemeriksaan keabsahan data yang menafsirkan sesuatu yang lain di luar untuk keperluan pengecekan atau perbandingan terhadap data. Triangulasi yang 
digunakan dalam penelitian ini adalah triangulasi sumber data dengan cara "membandingkan data dan mengecek balik derajat kepercayaan suatu informasi yang diperoleh melalui waktu dan alat yang berbeda dalam metode kualitatif.

\section{Hasil dan Pembahasan}

Ketik Teks disini dengan font Times New Roman 12pt, spasi 1,15 dan dalam satu kolom. Subbab ini berisi paparan hasil analisis yang berkaitan dengan pertanyaan penelitian. Setiap hasil penelitian harus dibahas. Pembahasan berisi pemaknaan hasil penelitian dengan teori dan/atau hasil penelitian sejenis.

\section{Hasil Penelitian}

Pada penelitian tindakan kelas (PTK) ini dilakukan sebanyak 2 siklus dengan 4 kali pertemuan yaitu siklus I dengan 2 kali pertemuan dan siklus II juga 2 kali pertemuan masing-masing pertemuan sebanyak ( 2 x 35 menit) dengan mengambil materi pokok Bangun Datar Sederhana dan sifat-sifatnya. Adapun langkah-langkah tindakan pada tiap siklus dibagi menjadi beberapa langkah yaitu: (1) perencanaan (planning), (2) pelaksanaan (acting), (3) pengamatan (observating), dan (4) refleksi (reflecting).

\section{a. Hasil Penelitian Siklus I}

Pada siklus I dilaksanakan sebanyak 2 kali pertemuan.

\section{1) Pertemuan 1}

Pertemuan pertama dilaksanakan pada hari Rabu tanggal 12 Desember 2018 peneliti menetapkan pembelajaran sebanyak ( 2 x 35 menit) dengan mengambil materi pokok Bangun Datar Sederhana dengan Indikator Menjelaskan bangun datar berdasarkan ciri-cirinya (Persegi, persegi panjang, segitiga)

\section{2) Pertemuan 2}

Pertemuan kedua dilaksanakan pada hari Jum'at tanggal 14 Desember 2018 peneliti menetapkan pembelajaran sebanyak ( 2 x 35 menit) dengan mengambil materi pokok Bangun Datar Sederhana dengan indikator Mengklasifikasi bangun datar berdasarkan ciri-cirinya (Persegi, persegi panjang, segitiga).

Berdasarkan penerapan metode Talking stick pada siklus I yang dilakukan sebanyak 2 kali pertemuan di atas secara garis besar pelaksanaan langkah-langkah tindakan pada pertemuan tiap pertemuanya yaitu: (1) Perencanaan (planning), (2) Pelaksanaan (acting), (3) Pengamatan (observating), (4) Refleksi (reflecting).

Pada siklus 1 pertemuan pertama berhasil meski belum memenuhi target ketuntasan belajar pada materi pengenalan Bangun Datar. Berdasarkan siklus 1 kegiatan pembelajaran berjalan dengan lancar. Setiap siswa mengikuti pembelajaran 
dengan serius pada pembelajaran tematik tema 4 materi bangun datar dan mengerjakan tugasnya dengan penuh semangat. Suasana di kelas menjadi hidup (aktif) dan menyenangkan.

Pada siklus 1 pertemuan pertama sampai pertemuan kedua terjadinya peningkatan minds-on dan Hands-On siswa dapat dilihat pada tabel berikut berikut:

Tabel 2. Hasil kemampuan minds-on dan Hands-on siswa Siklus I

\begin{tabular}{|c|c|c|c|c|c|}
\hline \multirow{2}{*}{ No } & Identitas & \multicolumn{2}{|c|}{ Minds-On } & \multicolumn{2}{c|}{ Hands-on } \\
\cline { 3 - 6 } & Siswa & Pertemuan & Pertemuan & Pertemuan & Pertemuan \\
& & $\mathbf{1}$ & $\mathbf{2}$ & $\mathbf{1}$ & $\mathbf{2}$ \\
\hline 1 & DNI & 65 & 75 & 50 & 60 \\
\hline 2 & AMA & 72 & 79 & 65 & 70 \\
\hline 3 & DIA & 80 & 85 & 78 & 80 \\
\hline 4 & LKJ & 77 & 83 & 75 & 78 \\
\hline 5 & GHF & 82 & 90 & 80 & 82 \\
\hline 6 & WRH & 75 & 85 & 72 & 74 \\
\hline 7 & TID & 65 & 73 & 60 & 72 \\
\hline 8 & MKF & 83 & 87 & 78 & 80 \\
\hline 9 & ADF & 65 & 72 & 65 & 70 \\
\hline 10 & SIRT & 75 & 82 & 75 & 76 \\
\hline 11 & DUM & 80 & 88 & 77 & 79 \\
\hline 12 & KYU & 82 & 86 & 82 & 85 \\
\hline 13 & AMH & 70 & 78 & 70 & 75 \\
\hline 14 & BCG & 65 & 70 & 55 & 60 \\
\hline 15 & MHI & 78 & 80 & 78 & 78 \\
\hline 16 & MHU & 80 & 85 & 79 & 80 \\
\hline 17 & NKS & 82 & 87 & 77 & 78 \\
\hline 18 & DKT & 82 & 92 & 75 & 77 \\
\hline 19 & CBL & 75 & 82 & 71 & 75 \\
\hline 20 & INH & 80 & 86 & 78 & 80 \\
\hline Jumlah Nilai & 1513 & 1645 & 1440 & 1509 \\
\hline Nilai rata-rata & $\mathbf{7 5 , 6 5}$ & $\mathbf{8 2 , 2 5}$ & $\mathbf{7 2 , 1}$ & $\mathbf{7 5 , 4 5}$ \\
\hline & & & & & \\
\hline
\end{tabular}

Berdasarkan tabel 3.2 di atas pada pertemuan pertama tersebut nilai siswa lumayan baik, meskipun masih terdapat beberapa nilai siswa yang belum mencapai KKM 75 nilai terendah siswa pada siklus 1 yaitu 65. Perolehan nilai rata-rata kemampuan Minds-on siswa pada pertemuan 1 yaitu 75,65 dan pertemuan 2 sebesar 82,25, sedangkan kemampuan Hands-on siswa pada pertemuan 1 nilai rata-rata 72,1 dan pertemuan 2 sebesar 75,45.

\section{b. Hasil Penelitian Siklus II}


Pada siklus II dilaksanakan sebanyak 2 kali pertemuan.

\section{1) Pertemuan 1}

Pertemuan pertama dilaksanakan pada hari Rabu 19 Desember 2018 ini peneliti menetapkan pembelajaran sebanyak (2 x 35 menit) dengan mengambil materi pokok Bangun Datar Sederhana dengan indikator Menjelaskan bangun datar berdasarkan ciricirinya (trapesiaum, belahketupat, jajar genjang dan lingkaran).

\section{2) Pertemuan 2}

Pertemuan kedua dilaksanakan pada hari Jum'at 21 Desember 2018 peneliti menetapkan pembelajaran sebanyak ( 2 x 35 menit) dengan mengambil materi pokok Bangun Datar Sederhana dengan indikator Mengklasifikasi bangun datar berdasarkan ciri-cirinya (trapesiaum, belahketupat, jajar genjang dan lingkaran).

Berdasarkan penerapan metode Talking stick pada siklus II yang dilakukan sebanyak 2 kali pertemuan di atas secara garis besar pelaksanaan langkah-langkah tindakan pada pertemuan tiap pertemuanya yaitu: (1) Perencanaan (planning), (2) Pelaksanaan (acting), (3) Pengamatan (observating), (4) Refleksi (reflecting).

Pada siklus II pertemuan pertama terdapat 5 siswa yang nilainya kurang dari Ketuntasan Minimum (KKM) dan pada pertemuan kedua terdapat 2 siswa yang nilainya belum mencapai KKM. Berdasarkan siklus II kegiatan pembelajaran berjalan dengan lancar. Setiap siswa mengikuti pembelajaran dengan serius. Siswa mengikuti penjelasan pelajaran Bangun Datar dan mengerjakan tugasnya dengan penuh semangat. Suasana di kelas menjadi hidup (aktif) dan menyenangkan.

Pada pertemuan pertama sampai kedua nilai siswa terjadi peningkatan, walaupun masih terdapat 2 siswa yang nilainya belum mencapai KKM yang ditetapkan MI Sunan Giri Merjosari Malang yakni 75. Siswa yang mendapatkan nilai di bawah KKM memang siswa yang kurang fokus dalam pembelajaran.

Pada siklus II pertemuan pertama dan kedua terjadinya peningkatan minds-on siswa dapat dilihat pada tabel berikut berikut:

Tabel 3. Hasil kemampuan minds-on dan Hands-on siswa Siklus II

\begin{tabular}{|c|c|l|l|l|l|}
\hline \multirow{2}{*}{ No } & \multirow{2}{*}{$\begin{array}{c}\text { Identitas } \\
\text { Siswa }\end{array}$} & \multicolumn{2}{|c|}{ Minds-On } & \multicolumn{2}{c|}{ Hands-on } \\
\cline { 3 - 6 } & & $\begin{array}{c}\text { Pertemuan } \\
\mathbf{1}\end{array}$ & $\begin{array}{c}\text { Pertemuan } \\
\mathbf{2}\end{array}$ & $\begin{array}{c}\text { Pertemuan } \\
\mathbf{1}\end{array}$ & $\begin{array}{c}\text { Pertemuan } \\
\mathbf{2}\end{array}$ \\
\hline 1 & DNI & 80 & 82 & 72 & 75 \\
\hline 2 & AMA & 72 & 78 & 75 & 77 \\
\hline 3 & DIA & 80 & 85 & 80 & 84 \\
\hline 4 & LKJ & 82 & 86 & 80 & 82 \\
\hline 5 & GHF & 82 & 90 & 84 & 85 \\
\hline
\end{tabular}




\begin{tabular}{|c|c|l|l|l|l|}
\hline 6 & WRH & 85 & 95 & 78 & 80 \\
\hline 7 & TID & 78 & 84 & 74 & 76 \\
\hline 8 & MKF & 80 & 86 & 82 & 85 \\
\hline 9 & ADF & 83 & 86 & 72 & 74 \\
\hline 10 & SIRT & 82 & 85 & 78 & 81 \\
\hline 11 & DUM & 82 & 85 & 80 & 82 \\
\hline 12 & KYU & 70 & 78 & 85 & 87 \\
\hline 13 & AMH & 85 & 92 & 76 & 79 \\
\hline 14 & BCG & 95 & 98 & 65 & 70 \\
\hline 15 & MHI & 85 & 90 & 80 & 83 \\
\hline 16 & MHU & 87 & 92 & 82 & 86 \\
\hline 17 & NKS & 80 & 80 & 80 & 86 \\
\hline 18 & DKT & 80 & 82 & 78 & 80 \\
\hline 19 & CBL & 68 & 74 & 76 & 78 \\
\hline 20 & INH & 80 & 82 & 82 & 85 \\
\hline Jumlah Nilai & $\mathbf{1 6 1 6}$ & $\mathbf{1 7 1 0}$ & $\mathbf{1 5 5 9}$ & $\mathbf{1 6 1 5}$ \\
\hline Nilai rata-rata & $\mathbf{8 0 , 8}$ & $\mathbf{8 5 , 5}$ & $\mathbf{7 8 , 1}$ & $\mathbf{8 0 , 9 5}$ \\
\hline
\end{tabular}

Berdasarkan tabel 2 dan 3 di atas terkait dengan penggunaan Metode Talking Stick dapat meningkatkan baik kemampuan Minds-On dan Hans-On siawa terbukti melalui hasil penilaian belajar materi Bangun Datar baik siklus I dan siklus II Minds-on pada siklus I sejumlah 82,25 dibanding dengan nilai Minds-on pada siklus II sejumlah 85,5 peningkatan sebesar 3.25. Begitu pula dengan penilaian Hans-On juga terdapat peningkatan antara Siklus I sejumlah 75,45 dan siklus II sejumlah 80,95 peningkatan sebesar 5,5.

\section{Pembahasan}

a. Analisis Penerapan Metode Talking Stick Materi Bangun Datar Kelas IV di MI Islamiah Dinoyo Terdepan Deket Lamongan

Metode talking stick termasuk salah satu metode pembelajaran yang dilakukan dengan bantuan tongkat, siapa yang memegang tongkat wajib menjawab pertanyaan dari guru setelah siswa mempelajari materi pokoknya. Pembelajaran talking stick sangat cocok diterapkan di SD, karena selain melatih kemapuan psikomotor dan kognitif, pembelajaran ini menciptakan suasana yang menyenangkan dan membuat siswa aktif (Sibuea \& Syahfitri, 2018).

Langkah-langkah yang dapat dilakukan dalam model pembelajaran ini sebagai berikut: 1) Guru menyiapkan sebuah tongkat; 2) Guru menyampaikan materi pokok yang akan dipelajari secara singkat, kemudian memberikan kesempatan kepada peserta didik untuk membaca dan mempelajari materi pegangannya; 3) siswa dipersilahkan untuk menutup bukunya; 4) Guru mengambil tongkat dan memberikan kepada siswa, 
setelah itu guru memberikan pertanyaan dan siswa yang memegang tongkat tersebut harus menjawabnya.

Hasil penelitian menunjukkan bahwasanya penerapan metode Talking Stick dapat dikatakan efektif dan efisien menimbulkan antusias siswa hal ini terbukti pada siklus I yang dilakukan sebanyak 2 kali pertemuan pada tanggal 12 dan 14 Desember 2018. Dapat diketahui bahwa awalnya masih banyak siswa yang merasa bingung dengan materi meski sudah diterangkan oleh guru dengan menggunakan metode talking stick. Hal ini dikarenakan siswa baru pertama kali melakukan metode yang baru diterapkan di sekolah mereka. Namun pada pertemuan ke-2 pada siklus I kemampuan siswa minds-on dan hands-on siswa semakin meningkat dan semangat anak mulai tumbuh.

Pada pelaksanaan siklus II yang dilaksanakan 2 kali pertemuan pada tanggal 19 dan 21 Desember 2018 dapat diketahui bahwa kondisi pembelajaran bisa lebih baik lagi karena siswa sudah terbiasa dengan metode talking stick dan siswa merasa senang jika berdiskusi dengan teman. Kelompok belajar ini tidak ada perbedaan antara siswa yang pandai dan kurang pandai karena setiap kelompok belajar dibentuk secara acak. Selain itu guru telah melaksanakan kegiatan pembelajaran sesuai dengan perencanaan pada rencana pelaksanaan pembelajaran (RPP) bersama peneliti. Pada siklus II ini, mulai terjadinya peningkatan kemampuan minds-on dan hands-on yang diperoleh oleh setiap kelompok. Setiap kelompok sudah mulai saling bekerjasama, lebih aktif bertanya, dan menjawab pertanyaan yang diajukan baik dari guru maupun siswa sendiri.

\section{b. Analisis Peningkatan Kemampuan Minds-On Dan Hands-On siswa Materi Bangun Datar dengan menggunakan Metode Talking stick Kelas IV di MI Islamiah Dinoyo Terdepan Deket Lamongan}

Kemampuan Mins-On (disebut juga kemampuan kognitif), kemampuan psikologis manusia yang yang meliputi setiap perilaku mental yang berhubungan dengan pemahaman, pertimbangan, pengolahan informasi, pemecahan masalah, kesengajaan, dan keyakinan (Syah, 2010). Sedangkan Kemampuan hands-on (disebut juga psikomotor) merupakan kemampuan yang progresif dan berhubungan dengan perolehan aneka ragam ketrampilan fisik anak (motor skill). Menurut Howe, hal ini mengingat pola-pola gerakan yang cakap dan terkoordinasi itu tak dapat mencapai dengan baik semata-mata dengan mekanisme sederhana, tetapi dengan menggunakan proses mental yang sangat kompleks (Desmita, 2010).

Hasil penelitian menunjukkan bahwasanya penggunaan metode Talking Stick dapat meningkatkan kemampuan Minds-On Dan Hands-On siswa Materi Bangun Datar di MI Sunan Giri Merjosari Malang secara signifikan. Hal ini terbukti melalui hasil penilaian belajar materi Bangun Datar baik siklus I dan siklus II kemampuan Minds-on pada siklus I sejumlah 82,25 dibanding dengan nilai Minds-on pada siklus II sejumlah 85,5 
terjadi peningkatan sebesar 3.25. Begitu pula dengan penilaian kemampuan Hans-On juga terdapat peningkatan antara Siklus I nilai rata-rata sejumlah 75,45 dan siklus II sejumlah 80,95 terjadi peningkatan sebesar 5,5. Berdasarkan hasil analisis data penelitian tersebut dapat disimpulkan bahwa pengunaan metode talking stick dapat meningkatkan kemampuan minds-on dan hands-on pada materi Bangun Datar serta pelaksanaannya dapat berjalan dengan efektif dan efesien.

\section{Simpulan}

Berdasarkan pemaparan hasil penelitian dan pembahahasan di atas dapat disimpulkan beberapa hal berkaitan dengan penggunaan metode Talking Stick terhadap kemampuan Minds-On Dan Hans-On pada penerapan metode Talking Stick pada pembelajaran Tematik kelas II tema 4 Materi Bangun Datar dan sifat-sifatnya di MI Sunan Giri Merjosari Malang menunjukkan bahwasanya penerapan metode Talking Stick pada siklus I dapat dikatakan efektif dan efisien menimbulkan antusias siswa, dan pada pelaksanaan siklus II dapat diketahui bahwa kondisi pembelajaran bisa lebih baik lagi karena siswa sudah terbiasa dengan metode talking stick dan siswa merasa senang jika berdiskusi dengan teman.

Hasil penelitian menunjukkan bahwasanya penggunaan metode Talking Stick dapat meningkatkan kemampuan Minds-On Dan Hands-On siswa pada pembelajaran tematik kelas II tema 4 Materi Bangun Datar dan sifat-sifatnya di MI Sunan Giri Merjosari Malang secara signifikan. Hal ini terbukti melalui hasil penilaian hasil belajar materi Bangun Datar baik siklus I dan siklus II kemampuan Minds-on pada siklus I sejumlah 82,25 dibanding dengan nilai Minds-on pada siklus II sejumlah 85,5 terjadi peningkatan sebesar 3.25. Begitu pula dengan penilaian kemampuan Hans-On juga terdapat peningkatan antara Siklus I nilai rata-rata sejumlah 75,45 dan siklus II sejumlah 80,95 terjadi peningkatan sebesar 5,5. Berdasarkan hasil analisis data penelitian tersebut dapat disimpulkan bahwa pengunaan metode talking stick dapat meningkatkan kemampuan minds-on dan hands-on pada pembelajaran tematik kelas II tema 4 Materi Bangun Datar dan sifat-sifatnya di MI Sunan Giri Merjosari Malang serta pelaksanaannya dapat berjalan dengan efektif dan efesien.

\section{Daftar Rujukan}

Afandi, M. (2013). Model dan Motode Pembelajaran. In Unissula press.

Agus Suprijono. (2010). Cooperative Learning Teori dan Paikem. Kumpulan Metode Pembelajaran.

Arikunto, S. (2006). Prosedur Penelitian Tindakan Kelas. Bumi Aksara.

Desmita. (2010). Psikologi Perkembangan Cetakan Ke-IV. Bandung: PT. Remaja

Rosdakarya Offset. https://doi.org/10.1017/CBO9781107415324.004 
Gugus, D. I., Kecamatan, V. I., Heriasa, I. K., Arini, N. W., \& Rati, N. W. (2014). PENGARUH METODE TALKING STICK TERHADAP HASIL BELAJAR IPA SISWA KELAS V SD NEGERI 1 KARANGASEM TAHUN PELAJARAN 2013/2014. PENGARUH METODE TALKING STICK TERHADAP HASIL BELAJAR IPA SISWA KELAS V SD NEGERI 1 KARANGASEM TAHUN PELAJARAN 2013/2014.

Hendriana, H., \& Afrilianto, M. (2017). Langkah Praktis Penelitian Tindakan Kelas Bagi Guru. Bandung: Refika Aditama.

Heruman. (2008). Model Pembelajaran Matematika di Sekolah Dasar. Bandung: PT Remaja Rosdakarya.

Indriani, O. (2013). Upaya Meningkatkan Kemampuan Mengidentifikasi Keanekaragaman Budaya Indonesia Melalui Metode Talking Stick. Didaktika Dwija Indria.

Kusumo, G. (2017). Metode Pembelajaran. Macam Metode Pembelajaran.

Langgulung, H. (1988). Asas-Asas Pendidikan Islam. Pustaka Al-Husna.

Moleong, L. J. (2017). Metodologi Penelitian Kualitatif (Edisi Revisi). In PT. Remaja Rosda Karya.

Sanjaya, W. (2010). Strategi Pembelajaran Berorientasi Standar Proses Pendidikan. System.

Sibuea, M. S. W. B., \& Syahfitri, D. (2018). Metode Tongkat Berbicara (Talking Stick) dalam Pembelajaran Keterampilan Berbicara Menanggapi Cerita Pendek. Jurnal Penelitian Dan Pengembangan Sains Dan Humaniora. https://doi.org/10.23887/jppsh.v2i1.14007

Suharjana, A. (2008). Pengenalan Bangun Datar dan Sifat-Sifatnya di SD. Yogyakarta: Pusat Pengembangan dan Pemberdayaan Pendidik dan Tenaga Kependidikan Matematika.

Sutikno, M. S., \& Fathurrohman, P. (2010). Strategi Belajar Mengajar Melalui Penanaman Konsep Umum \& Konsep Islami. Bandung: Refika Aditama.

Syah, M. (2010). Psikologi Pendidikan dengan pendekatan Baru. Psikologi Pendidikan dengan pendekatan Baru.

Tarigan, D. (2018). MENINGKATKAN HASIL BELAJAR SISWA DENGAN MENGGUNAKAN MODEL REALISTIC MATHEMATICS EDUCATION (RME) PADA MATA PELAJARAN MATEMATIKA DI KELAS V SDS SALSA CINTA RAKYAT. ELEMENTARY SCHOOL JOURNAL PGSD FIP UNIMED. https://doi.org/10.24114/esjpgsd.v8i4.11878

Wahidmurni. (2008). Penelitan Tindakan Kelas Dari Teori Menuju Praktik. Malang: UM PRESS. 